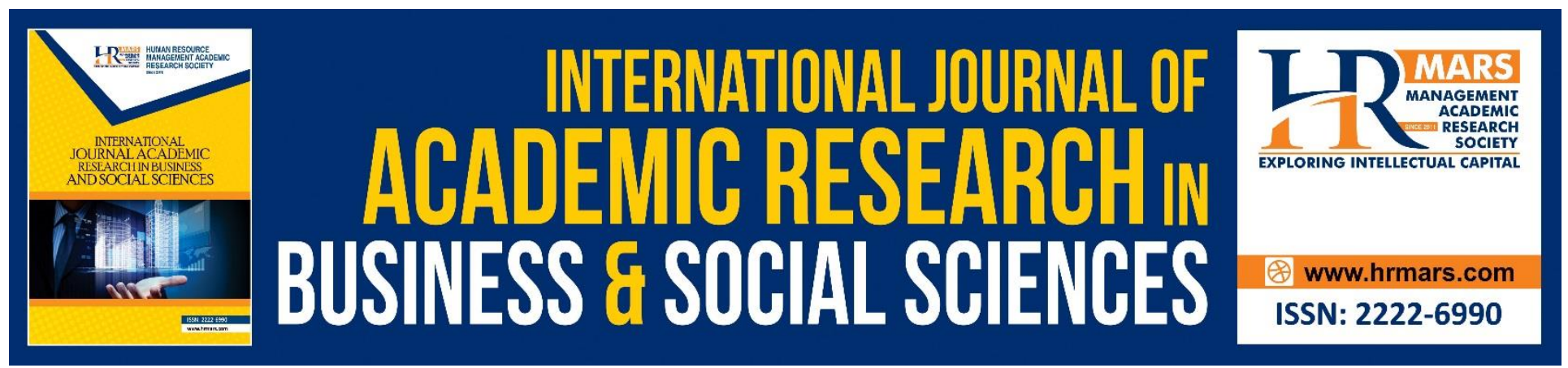

\title{
Corporate Governance Practices among Malaysian Public Universities
}

Fauzilah Salleh, Muhammad Esma Hakim Muhammad Sukri, Wan Abdul Rahman Wan Harun, Ahmad Shukri Yazid, and Nik Mohd Fadzilah Nik Mohd Rashid

To Link this Article: http://dx.doi.org/10.6007/IJARBSS/v8-i12/5214

DOI: $10.6007 /$ IJARBSS/v8-i12/5214

Received: 11 Nov 2018, Revised: 23 Dec 2018, Accepted: 05 Jan 2018

Published Online: 10 Jan 2018

In-Text Citation: (Salleh, Sukri, Harun, Yazid, \& Rashid, 2018)

To Cite this Article: Salleh, F., Sukri, M. E. H. M., Harun, W. A. R. W., Yazid, A. S., \& Rashid, N. M. F. N. M. (2018). Corporate Governance Practices among Malaysian Public Universities. International Journal of Academic Research in Business and Social Sciences, 8(12), 1301-1313.

\section{Copyright: (C) 2018 The Author(s)}

Published by Human Resource Management Academic Research Society (www.hrmars.com)

This article is published under the Creative Commons Attribution (CC BY 4.0) license. Anyone may reproduce, distribute, translate and create derivative works of this article (for both commercial and non-commercial purposes), subject to full attribution to the original publication and authors. The full terms of this license may be seen

at: http://creativecommons.org/licences/by/4.0/legalcode

Vol. 8, No. 12, 2018, Pg. 1301 - 1313

Full Terms \& Conditions of access and use can be found at http://hrmars.com/index.php/pages/detail/publication-ethics 


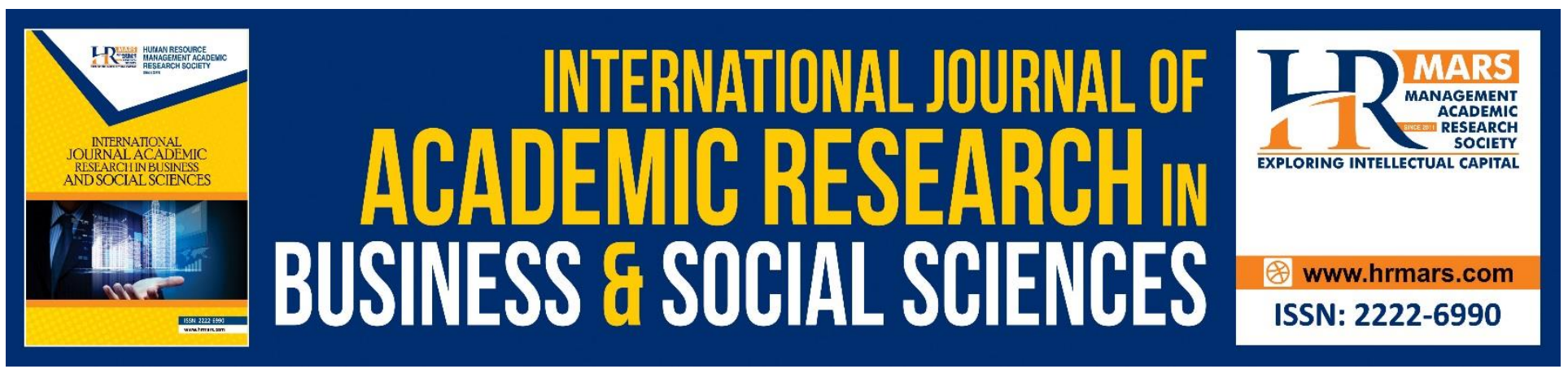

\title{
Corporate Governance Practices among Malaysian Public Universities
}

\section{Fauzilah Salleh, Muhammad Esma Hakim Muhammad Sukri, Wan Abdul Rahman Wan Harun, Ahmad Shukri Yazid, and Nik Mohd Fadzilah Nik Mohd Rashid}

Faculty of Economics and Management Sciences, Universiti Sultan Zainal Abidin,

21300 Kuala Nerus, Terengganu, Malaysia

Email: fauzilah@unisza.edu.my

\begin{abstract}
The objective of this paper is to explore the corporate governance practice and performance among public universities through Malaysian Code on Corporate Governance (MCCG) 2012. The data was collected through interviewing the Board of Directors (BOD) of a university based on the university's MCCG 2012 and annual report. The finding of this research can be used as a reference to boost the performance of Malaysian public universities by fostering their governance. This research particularly shed some lights on the requirement of good governance practices that is expected to have positive impact on the university's performance.
\end{abstract}

Keywords: Corporate Governance, Malaysia Code on Corporate Governance, Board of Director, Public University, Autonomy

\section{Introduction}

This paper discusses about the implementation of corporate governance among public universities in Malaysia. Corporate governance is a famous research area after the incident of the Asian financial crisis in 1997 (Adegbite, 2010). Unfortunately, the corporate governance scandals have caused various issues that slow down the enhancement process by the Malaysian government. According to the Malaysian Code on Corporate Governance (MCCG) 2012, corporate governance is generally defined as:

"The process and structure used to direct and manage the business affairs of the company towards enhancing business prosperity and corporate accountability with the ultimate objective of realizing long-term shareholder value, whilst taking into account the interests of other stakeholders." 
INTERNATIONAL JOURNAL OF ACADEMIC RESEARCH IN BUSINESS AND SOCIAL SCIENCES Vol. 8, No. 12, Dec, 2018, E-ISSN: 2222-6990 @ 2018 HRMARS

Undoubtedly, the requirements for setting up corporate governance are crucial. The conflict of interest is likely to separate the ownership of the shareholders from the management (H Khan, 2011). As mentioned by the President of Malaysian Institute of Corporate Governance, although Malaysian public universities have implemented both corporate governance framework and regulatory framework, the universities lack knowledge about governance (Iskandar, Rahmat, \& Noor, 2011). It is suggested that the governance education should be widen before the discussions about codes take place. However, the implementation of corporate governance culture is unusual (Rupinder Singh, 2013). A few groups of researchers (Gompers, Ishii, \& Metrick, 2003; Klapper, Laeven, \& Love, 2006; Drobetz, Schillihofer, \& Zimmermann, 2004; Brown \& Caylor, 2006) highlighted that a good governance ensures excellent performance. Based on the 10th Malaysia Plan (2010-2015), reliable corporate governance can be accomplished by the experienced directors and managers working in the public sector, because they understand the corporate governance better.

The Board of Directors (BOD) has to practice effective corporate governance to facilitate organizational performance (Barney, 1991). The Board should consist of knowledgeable experts who are able to provide deliberate suggestions for improving an organization. Furthermore, the Board has to represent the shareholders in performing business activities. Specifically, each director has to discharge his or her responsibility by updating the company's strategies and policies, and looking closely into the performance of other independent directors. In this regard, the Board should be wellorganized to allow the independent directors to take part in business activities that cause potential conflict of interest. Also, the Board committees should learn and apply relevant skills, experiences, independence, and knowledge that further aid them in carrying out their duties and responsibilities effectively.

According to the University Transformation Programme (UniTP) Book, the BOD bears the responsibility to support the Vice Chancellor's duties in order to accomplish organizational goals, which are compliant with the Ministry's requirements, ensuring that all activities in universities are consistent with the circulars and directives. Basically, the UniTP is one of the reliable guidelines a university can follow to strengthen its governance. In October 2011, an Educational Blueprint was developed by the Ministry of Education, which intended to delineate the vision of the current Malaysian education system comprehensively. In this Blueprint, there are 11 strategic and operational changes our country needs to focus. The Blueprint attempts to review the list of challenges, reinforce the basis of existing policies, and ensure the continuous betterment of education system. In today's demanding business environment, a university should be prepared for the challenges to achieve a better state of governance.

This study discusses about the difficulties Malaysian public universities have, particularly staffing and budget allocation. Most of these universities suffer from fund shortage to restructure since they have no autonomy power. In this regard, the universities must portray better corporate governance and be efficient in auditing by using the "Code of University Good Governance" and "University Good Governance Index". Besides, autonomy power can strengthen the decision-making of Malaysian public universities without government intervention. Nevertheless, 17 out of 21 universities are 
INTERNATIONAL JOURNAL OF ACADEMIC RESEARCH IN BUSINESS AND SOCIAL SCIENCES

Vol. 8, No. 12, Dec, 2018, E-ISSN: 2222-6990 C 2018 HRMARS

known to have effective corporate governance with full autonomy. There have been eight principles of Malaysian Code on Corporate Governance used to examine the governance practices among Malaysian public universities. Therefore, the main objective of this research is to determine whether the Malaysian public universities comply with the principles of MCCG 2012.

\section{Literature Review}

Higher education management is associated with the governance and management of knowledge workers and knowledge system (Meek and Davies, 2009). In fact, university has a specific corporate governance that enjoys considerable attention (Stefenhagena, 2012). Corporate governance helps an organization to achieve its goals and performance. Generally, corporate governance is defined in an institution's theoretical environment (Campbell, 2007; Franzen, Hobma, \& De Jonge, 2011).

Currently, there are 21 public universities in Malaysia. Among public universities, five of them are research universities, four are comprehensive universities, and the remaining 11 are focused universities. The Ministry of Higher Education (MoHE) is responsible for allocating budget to public universities. They are involved in the governance by appointing pro counselor and audit management team universities to ensure the accountability. In fact, a university's status must be established in compliance with the provisions of the Universities and University Colleges Act 1971 or the Private Higher Education Institutions Act 1996.

According to Shattock (2002), university governance is defined as how university administration bodies work, the relationship between governance and management, and its responsibility to determine strategy. Basically, the MoHE adopts Malaysian Research Assessment Instrument (MyRA) to measure the performance of Malaysian public universities (Yassin et al., 2012). The function of MyRA is to gauge the performance of the universities based on the requirements stated in the objectives and plan of strategic. In other words, the governance in a university is considered as a form of corporate governance that receives considerable attention (Stefenhagena, 2012). The role of a university can be represented by the BOD.

Furthermore, BOD is one of the vital instruments in internal corporate governance because there is a positive relationship between board performance and firm performance (Kamardin \& Haron, 2011). BOD is crucial to ensure the effectiveness of board performance by implementing strategic and innovative plans. It has to reinforce the purpose of applying an organization's processes (Coles et al., 2001). According to the Clause III Section 6(1) of Universities and Universities Colleges Act 1971, the Board needs to implement policy and monitors the university activities. The Board also has to fulfil its duty given by the university according to the statutes, constitution, or rules and regulations. The BOD is accountable to upgrade the university and secure a fund for it (Sohail Inayatullah, Ivana Milojevic, 2016).

Considering perpetual transformation, renovation, discussion of the state, leadership, and governance, some interested parties are keen to understand about the underlying dimensions of governance and management systems in the public universities. 
INTERNATIONAL JOURNAL OF ACADEMIC RESEARCH IN BUSINESS AND SOCIAL SCIENCES

Vol. 8, No. 12, Dec, 2018, E-ISSN: 2222-6990 C 2018 HRMARS

\section{Research Methodology}

\section{Content Analysis}

The objective of this study is to identify whether a public university adheres to the principles of MCCG 2012 , and its role of BOD on corporate governance practices. The sample was BOD from a public university without autonomy. A content analysis was conducted based on previous articles to comprehend the implementation of MCCG 2012 in a public university. According to Weber (1990), content analysis is a set of procedures used to make valid inferences from text and trend analysis in social sciences (Gul et al., 2012; Bayramusta \& Nasir, 2016).

Figure 1 depicts the process of content analysis. It began with sample selection from the articles. The next stage specified the unit of analysis. Then, it is followed by interview session with the university's BOD. The entire process took place at the final stage before the findings could be obtained.

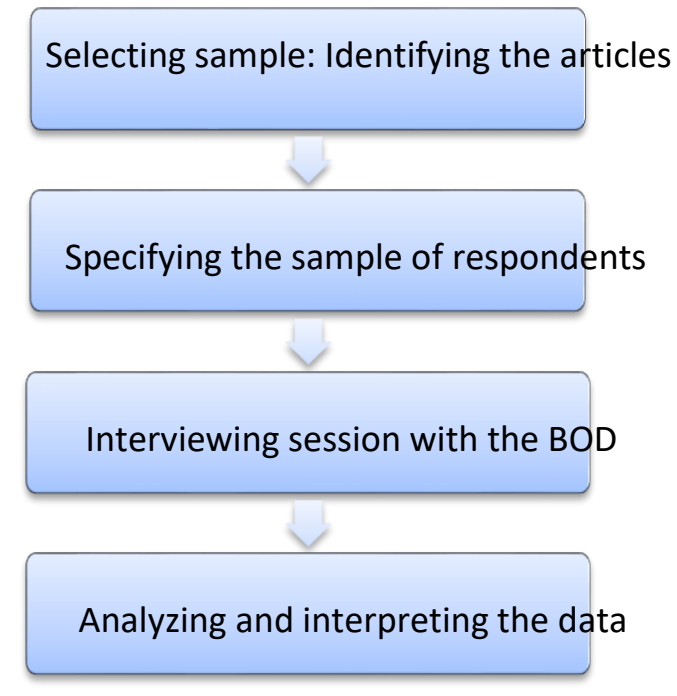

Figure 1: Phases of content analysis

\section{Specifying the sample of respondents}

Given that only one university was considered in this study, two out of 11 members of the university's BOD were chosen to participate the interview session due to their unique role and responsibility. These two respondents were members of Audit and Risk Committee, and Recruitment and Remuneration Committee.

\section{Interview}

Interview is a verbal conversation between two or more people to collect useful information that meet the objective of a research. Interview is particularly effective to comprehend a participant's experiences (McNamara, 1999). Basically, there are two types of interview methods, structured or standardized interview and unstructured or conversational interview.

To achieve the objective of this study, unstructured interview was chosen due to its flexibility. The questions are asked according to the interviewees' responses. During the interview session, the 
INTERNATIONAL JOURNAL OF ACADEMIC RESEARCH IN BUSINESS AND SOCIAL SCIENCES

Vol. 8, No. 12, Dec, 2018, E-ISSN: 2222-6990 @ 2018 HRMARS

interviewers focused on the mission and allowed the interviewees to share their views freely. All the questions asked were adapted from the principles of MCCG 2012.

\section{Analyzing and interpreting the data}

To analyze the data, thematic analysis was used. This analysis is commonly used method in qualitative research. The process looked into the importance of the corporate governance and MCCG Principles, which are compliant with the management of the university.

\section{Finding and Discussion}

This section discusses about the qualitative data collected from the Board of Directors from a university. The interview questions are adapted from eight principles of MCCG: Principle 1 - To establish clear roles and responsibilities, Principle 2 - To strengthen the composition, Principle 3-

To reinforce independence, Principle 4 - To foster commitment, Principle 5 - To uphold the integrity in financial reporting, Principle 6 - To recognize and manage risks, Principle 7 - To ensure timely and high quality disclosure, and Principle 8 - To strengthen the relationship between company and shareholders. The discussion deepened the interview findings from the two respondents and captured the differences between their views.

\section{Principle 1 - To establish a set of clear roles and responsibilities}

Principle 1 states that the BOD is accountable for establishing board charter, management oversight, strategy mission premise on sustainability, and code of conduct. Both respondents assured that the BOD is able to define the functions clearly. Each board member also heads a department in the university such as remuneration and recruitment, Takaful, and audit. Thus, he or she will be the delegate from the management. The respondents agreed that the main role of BOD is to enhance the university's policy on strategic plan. Most importantly, they have unique experiences and qualifications. In fact, every member is appointed as the Head of Remuneration and Recruitment.

"The strategic plan is designed to follow the channel strictly before it is proposed to the Board of Director. The process is initiated by the Academic Deans. Then, it moves on to the Jabatan Pengurusan Pembangunan (JPP). Finally, the strategic plan is passed to the Faculty Senates for approval, reenactment or rejection".

Generally, the BOD is backed by a University Secretary. The University Secretary is obligated to address all the deliberations, issues, and inquiries from the Board's meeting. Based on the interview, several universities do not enforce any code of conduct since they are not given autonomy.

\section{Principle 2 - To strengthen the composition}

Principle 2 states that the Board should implement transparent policies and procedures before member selection. The Board is obliged to form the Nominating Committee to develop, maintain and review the members' criteria for appointment purpose. However, the respondents stated that there is no Nomination Committee in their university. In corporate governance, a company has a full autonomy in appointing board members to improve the performance of the Corporation. The 
INTERNATIONAL JOURNAL OF ACADEMIC RESEARCH IN BUSINESS AND SOCIAL SCIENCES

Vol. 8, No. 12, Dec, 2018, E-ISSN: 2222-6990 C 2018 HRMARS

respondents also highlighted that the University Board can only be appointed by the MoHE since the BOD is not empowered to recruit new members. In addition, the respondents were asked how the appointment of BOD takes place in Malaysian public universities.

"We do not have the power to appoint new member. This is the responsibility of MoHE, but the Board may give suggestion of qualified person to be appointed".

However, the Board was recommended by the University Board of Director, whereas the remuneration policies and procedures were provided by the MoHE.

\section{Principle 3 - To reinforce the independence}

According to Beasley (1996), outside independent directors are able to minimize the possibility of financial fraud. Undeniably, they watch over the management of a company. As mentioned by the respondents, eight of the ten members are non-executives. In fact, the Independence of Director shall be evaluated by the BOD annually.

"Appointing additional Independent Directors is expected to accelerate the performance of the BOD and networking between Malaysian public universities. I strongly agree if these universities can appoint BOD representatives from various industries, thus no members can serve more than 8 years".

Both the respondents contended that none of the members served the Board as independent nonexecutive directors exceeding 9 years. These members, with different backgrounds, will be appointed as representatives. In fact, the institution has two representatives from the MoHE, one representative is from industry, two representatives are from community, Vice Chancellor and one representative represents the management team from the institution.

\section{Principle 4 - To foster the commitment}

In public universities, it is crucial for the Board members to participate suitable education programs that enrich their knowledge and skills. All the members are encouraged to take up programs relating to the development of corporate governance, they are committed to board room dynamism and responsible for being Board Committees. Each director has to enhance his or her knowledge about accounting, finance, banking, general business, environment, health, safety, or human resource management.

"All directors are expected to attend at least one full-day training program each year in a team, they are also encouraged to attend training programs individually depending on the subject matter decided by the Board. Training may be different based on each individual director's needs. For your information, the Board members attended a training program on integrity last week in Kuala Lumpur". 


\section{Principle 5 - To uphold the integrity in financial reporting}

The Board provides a comprehensive assessment of the financial performance in all the disclosures made to the stakeholders and regulatory authorities. The financial statement proves the Board's commitment to disclosing transparent information to both the public and stakeholder. Moreover, it is assisted by the Audit and Risk Committee in governing a university's financial reporting and its quality.

"We have disclosed our financial report without any troubles. If the financial report is not published, something goes wrong".

\section{Principle 6 - To recognize and manage risk}

The risk management framework can be linked with the governance and management structure of the Malaysian public universities to provide a set of expectations and accountabilities. The BOD will be aided by the Audit and Risk Committee. The members are required to address every possible risk within the university by adopting the principles of risk management relating to the International, Risk Management Standard - MS ISO 31000:2010 Risk Management - Principles and Guidelines.

In addition, the universities form an internal audit team that reports to the Audit and Risk Committee. This Committee needs to ensure that the internal audit has sufficient resources to carry out its tasks smoothly.

"As in our university, we have "Pusat Tanggungjawab Audit Dalam" to report directly to the University's Audit Committee".

\section{Principle 7 - To ensure timely and high quality disclosure}

As stated in Recommendation 7.1, the Board needs to ensure that the company has strong corporate disclosure policies and procedures. Both respondents highlighted that

"We have our corporate disclosure policies and we ensure those stakeholders with accuracy and comprehensiveness".

Furthermore, Recommendation 7.2 points out that the Board should encourage the company to use technology for disseminating the information effectively. As raised up by the respondents, "We have created a website that allows the public and stakeholders to obtain the latest information about the activities the university is undertaking. Concurrently, they can obtain the financial information in our annual report in the library".

Principle 8 - To strengthen the relationship between company and shareholders

Recommendation 8.1 highlights that the BoD should encourage its shareholders to attend the Annual General Meeting. In this case, both the respondents said that 
INTERNATIONAL JOURNAL OF ACADEMIC RESEARCH IN BUSINESS AND SOCIAL SCIENCES Vol. 8, No. 12, Dec, 2018, E-ISSN: 2222-6990 C 2018 HRMARS

"We do not have shareholders in Malaysian public universities. We only have stakeholders such as MoHE, students, and parents."

Recommendation 8.2 asserts that the Directors should encourage shareholders to vote for the new members, but it is not possible to be implemented in Malaysian public universities. This is because they do not have shareholders to conduct the voting to appoint or renew the contract of the Directors. In fact, only MoHE is authorized to do so.

Moreover, Recommendation 8.3 underlines that the BOD should encourage effective communication and engagement with shareholders. Particularly, it is essential to have effective communication with stakeholders. The stakeholders and public can obtain material information including corporate information, university activities, financial report, and annual report.

Table 1: The Board Compliance with the Code of Corporate Governance of Malaysia

\begin{tabular}{|c|c|c|c|}
\hline No & Principles & Recommendations & Compliance \\
\hline 1.1 & & $\begin{array}{l}\text { The Board should establish clear } \\
\text { functions for itself and the management. }\end{array}$ & $\checkmark$ \\
\hline 1.2 & & $\begin{array}{l}\text { The Board should establish clear roles } \\
\text { and responsibilities to discharge its } \\
\text { fiduciary and leadership functions. }\end{array}$ & $\checkmark$ \\
\hline 1.3 & To establish clear roles & $\begin{array}{l}\text { The Board should implement ethical } \\
\text { standards through the adherence of } \\
\text { code of conduct. }\end{array}$ & 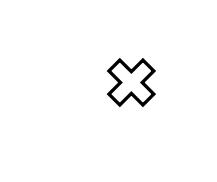 \\
\hline 1.4 & & $\begin{array}{l}\text { The Board should ensure that the } \\
\text { company's strategies are to promote } \\
\text { sustainability. }\end{array}$ & $\checkmark$ \\
\hline 1.5 & & $\begin{array}{l}\text { The Board should start up procedures } \\
\text { for its members to get information and } \\
\text { advice. }\end{array}$ & $\checkmark$ \\
\hline 1.6 & & $\begin{array}{l}\text { The Board should be supported by a } \\
\text { competent secretary. }\end{array}$ & $\checkmark$ \\
\hline 1.7 & & $\begin{array}{l}\text { The Board should formalize and } \\
\text { periodically review its board charter. }\end{array}$ & $\checkmark$ \\
\hline
\end{tabular}


INTERNATIONAL JOURNAL OF ACADEMIC RESEARCH IN BUSINESS AND SOCIAL SCIENCES Vol. 8, No. 12, Dec, 2018, E-ISSN: 2222-6990 C 2018 HRMARS

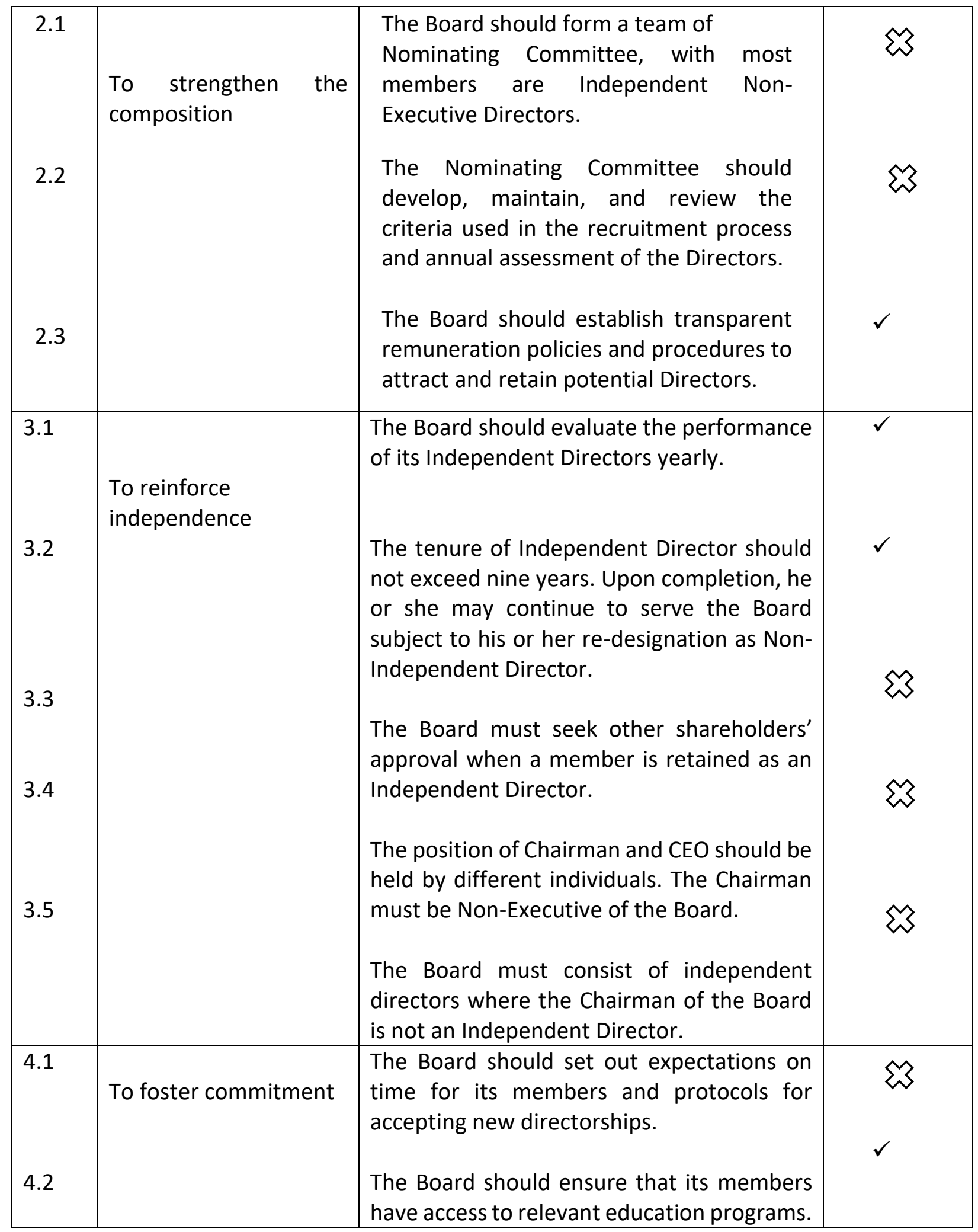


INTERNATIONAL JOURNAL OF ACADEMIC RESEARCH IN BUSINESS AND SOCIAL SCIENCES Vol. 8, No. 12, Dec, 2018, E-ISSN: 2222-6990 @ 2018 HRMARS

\begin{tabular}{|c|c|c|c|}
\hline 5.1 & $\begin{array}{l}\text { To uphold the integrity } \\
\text { in financial reporting }\end{array}$ & $\begin{array}{l}\text { The Audit Committee should ensure that the } \\
\text { financial statements are compliant with } \\
\text { applicable financial reporting standards } \\
\text { The Audit Committee should implement } \\
\text { policies and procedures to evaluate the } \\
\text { suitability and independence of the external } \\
\text { auditors. }\end{array}$ & $\checkmark$ \\
\hline 6.2 & $\begin{array}{l}\text { To recognize and } \\
\text { manage risks }\end{array}$ & $\begin{array}{l}\text { The Board should establish a sound } \\
\text { framework to manage risks. } \\
\text { The Board should establish an internal audit } \\
\text { function to report directly to the Audit } \\
\text { Committee. }\end{array}$ & $\checkmark$ \\
\hline 7.1 & $\begin{array}{l}\text { To ensure timely and } \\
\text { high quality disclosure }\end{array}$ & $\begin{array}{l}\text { The Board should ensure that the company } \\
\text { has appropriate corporate disclosure } \\
\text { policies and procedures. } \\
\text { The Board should encourage the company } \\
\text { to leverage information technology in order } \\
\text { to disseminate the information effectively. }\end{array}$ & $\checkmark$ \\
\hline 8.1 & $\begin{array}{l}\text { To strengthen the } \\
\text { relationship between } \\
\text { company and } \\
\text { shareholders }\end{array}$ & $\begin{array}{l}\text { The Board should encourage shareholders } \\
\text { to participate in general meeting. } \\
\text { The Board should encourage poll voting. }\end{array}$ & 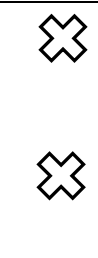 \\
\hline 8.3 & & $\begin{array}{l}\text { The Board should promote effective } \\
\text { communication and proactive engagement } \\
\text { with its shareholders. }\end{array}$ & $\checkmark$ \\
\hline
\end{tabular}

Table 1 shows the eight main principles of MCCG 2012, but only six of them are applicable to Malaysian public universities. Unfortunately, both Principle 2 and Principle 8 cannot be accomplished, because MoHe possesses absolute power to select the Board members. Also, public universities are non-profit organizations. Thus, 16 out of 26 recommendations of MCCG 2012 are applied by the university governance system and some are compliant with MCCG 2012 indirectly.

\section{Limitation and Future Research}

This study only focused on university governance from a Malaysian public university without autonomy power, and limited samples and documents. During data collection, researchers were given opportunity to review two years of the university's financial report, and we only managed to interview two Board members. Consider that there has been little research done on university 
INTERNATIONAL JOURNAL OF ACADEMIC RESEARCH IN BUSINESS AND SOCIAL SCIENCES

Vol. 8, No. 12, Dec, 2018, E-ISSN: 2222-6990 C 2018 HRMARS

governance system in Malaysia, the researchers had difficulty in understanding the research problems.

\section{Conclusion}

The findings indicated that public universities had implemented MCCG 2012 to improve the performance of governance system in Malaysia although it was not compulsory for them. The universities followed the University Transformation Plan Green Book (Corporate Governance) from MoHE, but its implementation is determined by MCCG 2012.

The implication MCCG 2012 principles brought was found to increase the performance of university's financial aspect and Board of Director. If a university is empowered to choose its members of the BOD, they will have a say in decision-making process for academic structure, staff appointment and dismissal, and tuition fee (Shah, Hussin and Soaib, 2009). However, the Board is not needed in Malaysian public universities because most decisions are made by the MoHE. Hence, the implementation of MCCG 2012 is important for the public universities to get complete autonomy from MoHE.

\section{References}

Adegbite, E. A. (2010). The determinants of good corporate governance: The case of Nigeria (Doctoral dissertation, Cass Business School).

Barney, J. (1991). Firm resources and sustained competitive advantage. Journal of management, 17(1), 99-120.

Bayramusta, M., \& Nasir, V. A. (2016). A fad or future of IT?: A comprehensive literature review on the cloud computing research. International Journal of Information Management, 36(4), 635-644.

Brown, L. D., \& Caylor, M. L. (2006). Corporate governance and firm valuation. Journal of accounting and public policy, 25(4), 409-434.

Campbell, J. L. (2007). Why would corporations behave in socially responsible ways? An institutional theory of corporate social responsibility. Academy of management Review, 32(3), 946967.

Drobetz, W., Schillhofer, A., \& Zimmermann, H. (2004). Corporate governance and expected stock returns: Evidence from Germany. European financial management, 10(2), 267-293.

Franzen, A. J., Hobma, H., de Jonge, H., \& Wigmans, G. (2011). Management of urban development processes in the Netherlands: governance, design, feasibility.

Gompers, P., Ishii, J., \& Metrick, A. (2003). Corporate governance and equity prices. The quarterly journal of economics, 118(1), 107-156.

Gul, S., Sajid, M., Razzaq, N., \& Afzal, F. (2012). Agency cost, corporate governance and ownership structure (the case of Pakistan).

Inayatullah, S., \& Milojevic, I. (2016). Leadership and governance in higher education 2025: can Malaysian universities meet the challenge?.Foresight, 18(4), 434-440. 
INTERNATIONAL JOURNAL OF ACADEMIC RESEARCH IN BUSINESS AND SOCIAL SCIENCES

Vol. 8, No. 12, Dec, 2018, E-ISSN: 2222-6990 C 2018 HRMARS

Iskandar, T. M., Rahmat, M. M., Noor, N. M., Saleh, N. M., \& Ali, M. J. (2011). Corporate governance and going concern problems: evidence from Malaysia. International Journal of Corporate Governance, 2(2), 119-139.

Kamardin, H., \& Haron, H. (2011). Internal corporate governance and board performance in monitoring roles: Evidence from Malaysia. Journal of Financial Reporting and Accounting, 9(2), 119-140.

Khan, H. (2011). A literature review of corporate governance. In International Conference on Ebusiness, Management and Economics (Vol. 25, pp. 1-5).

Klapper, L., Laeven, L., \& Love, I. (2006). Corporate governance provisions and firm ownership: Firmlevel evidence from Eastern Europe.Journal of International Money and Finance, 25(3), 429-444.

McNamara, C. (1999). General guidelines for conducting interviews, Minnesota. Missouri Institute of science.

Meek, L., \& Davies, D. (2009). Trend in Higher Education Governance. Websites of University World News, 1.

Rupinder Singh. 2013, March 20. Improving Corporate governance. The New straits Times. p. B9

Shah, N., Hossain, N., Shoaib, R., Hussain, A., Gillani, R., \& Khan, N. H. (2009). Socio-demographic characteristics and the three delays of maternal mortality. $J$ Coll Physicians Surg Pak, 19(2), 95-8.

Shattock, M. (2002). Re-balancing modern concepts of university governance. Higher Education Quarterly, 56(3), 235-244.

Stefenhagena, D. (2012). Problems of university institutional governance in changing environment. Economics and Management, 17(4), 1594-1599.

Yassin, N., Ghanem, M. G., \& Rustom, L. (2012). The role of internal audit function in corporate governance: An empirical study on commercial banks in Lebanon. In proceedings of the academic and business research institute conference, Orlando. Retrieved from http://www. aabri. com/OC2012Proceedings. html. 